\title{
THE INFLUENCE OF SOCIAL MEDIA IN LEARNING ENGLISH FOR HOSPITALITY AND TOURISM STUDENTS
}

\section{PENGARUH SOSIAL MEDIA DALAM PROSES PEMBELAJARAN BAHASA INGGRIS PADA PARA MAHASISWA HOSPITALITY DAN PARIWISATA}

\author{
Magdalena Kartika Sari Tandy Rerung ${ }^{1)}$ \\ ${ }^{1)}$ Bahasa dan Budaya Inggris, Universitas Bunda Mulia \\ Diterima Tanggal 10 Mei 2021 / Disetujui Tanggal 26 Mei 2021
}

\begin{abstract}
Since the beginning of the pandemic, education is challenged with the new method of online learning. With regards with the intervention of technology to the learning field, both students and teachers are able continue the teaching and learning process with several adjustments along the side. Social media can be one of the powerful tool during this process. Information such as text and visual are accessible based on these platforms. Therefore gaps between the what has been known and yet unknown is getting narrower. English as the main language in hospitality industry takes an important role in having an effective communication. From practice to the business world, the authenticity of information is also important. Based on the needs reviewed, the following study is discussing about the influence of social media, especially Facebook and Instagram toward the students language learning. The participants are taken from 63 Hospitality and Industry - Bunda Mulia University students who were taking General English as one of their course subjects. Results shown that most the students agree and extremely agree on how social media influence their language learning in various perspectives. Therefore as conclusions, educators as well teachers are encouraged to support their students in expressing their English whenever they use the social media platforms.
\end{abstract}

Keywords: language learning, hospitality and tourism

\begin{abstract}
ABSTRAK
Sejak awal pandemic, dunia pendidikan sudah dihadapi dengan berbagai metode pengajaran yang melibatkan teknologi didalamnya. Sehubungan dengan kemajuan teknologi dalam dunia pembelajaran, guru dan murid tetap dapat melangsungkan kegiatan belajar-mengajar ini walaupun harus melalui beberapa penyesuaian. Salah satu keterlibatan intenet dan teknologi dalam dunia pembelajaran adalah jejaring sosial media. Platform ini dapat menjadi salah satu alat pembelajaran yang efektif khususnya dalam menyampaikan informasi secara cepat. Jarak antara pengetahuan dan dunia praktis pun semakin kecil, khususnya melihat dunia industry hospitality yang banyak menggunakan komunikasi secara intensif. Bahasa Inggris merupakan salah satu bahasa yang cukup dominan penggunaannya dalam industry ini. Berdasarkan dari latar belakang ini, maka penelitian ini ditujukan untuk membahas peran sosial media khususnya bagi para mahasiswa. Lebih lanjut data yang diambil sejumlah 63 mahasiswa jurusan Hospitality dan Pariwisata Universitas Bunda Mulia yang mengambil mata kuliah Bahasa Inggris umum sebagai salah satu mata kuliah yang mereka ampu. Dari hasil penelitian, menunjukkan bahwa hampir sebagaian besar mahasiswa sangat setuju dengan penggunaan sosial media sebagai salah satu alat bantu dalam proses pembelajaran bahasa mereka dengan dilihat dari berbagai aspek. Sebagai kesimpulan, para guru dan pendidik sangat disarankan untuk mendukung para pembelajar ini untuk mengeskpresikan bahasa Inggris mereka ketika mereka mengakses sosial media tersebut.
\end{abstract}

Kata Kunci: pembelajaran bahasa, hospitality dan pariwisata 
Due to the pandemic, both students and teachers are positively forced to switch the education methods which is from face-to-face interaction to online interaction. The social and physical distancing policy encourage learning field in functioning various online tools in order to keep the process continuing even though lessons are delivered throughout distances. With the support of internet and technology, this becomes more possible even though both educators and learners have to effectively the new kinds of learning tools online.

However the problem may relies between the gap of communication between teachers and students. The wider the gap eventually influence the students' motivation in focusing on their learning progress. The different style of communication can somewhat reduce the students interaction either among themselves or towards the teachers.

Fortunately, there are various ways on how to maintain the students' interest through their learning progress, one of them is the usage of social networks. Even though the use of social network mostly used to entertain and becoming self-exposure recently, yet some benefits can also be witnessed based on some features offered by the social networks sites especially the social media. The increase on popularity of social networking sites such as Facebook and Twitter and increase in a number of social users allow the access to more resources in terms of learning and sharing.

Below are some data statistics showing how users of social media growing and which platform that mostly used by young-age users.

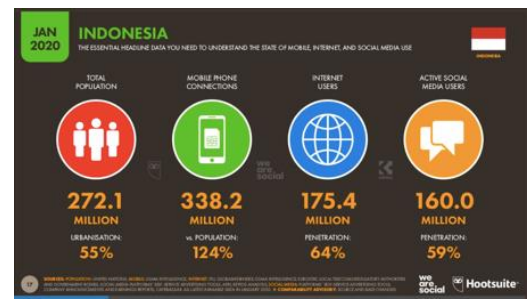

Source: datareportal

Image 1. Total Internet Users in Indonesia
Based on the graph, from $64 \%$ of internet users, $59 \%$ of them are also social media users. Furthermore the following data shows that population aged from 13 until 18 years old above covered around $69 \%$ to $77 \%$ based on the whole population by age group.

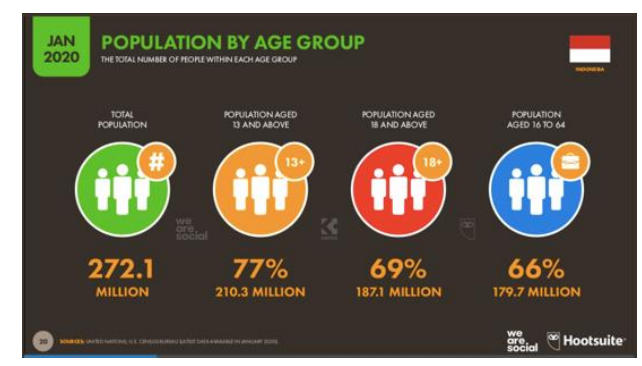

Source: datareportal

\section{Image 2. Population by aged on Internet Users in Indonesia}

Furthermore, looking from the time-allocation with social media shows that around 3 hours and 26 minutes per day spent by browsing the social media itself. For the most social media visited, the statistical data shows that Youtube, Whatsapp, Facebook, Instagram, and Twitter got the first five most used social media by the internet users. The data is shown as follows,

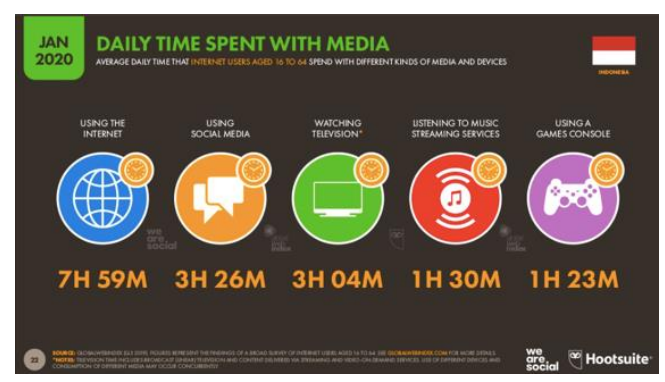

Source: datareportal

Image 3. Date Time Spent with Media



Source: datareportal 


\section{Image 4. Most-used Social Media Platform}

On the other hand, the learning process, social media plays it roles in share latest news, videos, educational subjects, interesting stories in terms of learning and sharing indicate that the use of social media can increase the communication effectively, therefore research studies show that social networks can be used for educational purposes and have a positive impact on students. Facebook is more often used for educational reasons by students in higher education, this is possible since Facebook offers grouping features that allows its users to have group discussions, exchanging information regarding to the topic made. ((Bicen \& Uzunboylu, 2013). Furthermore some other benefits in using Facebook for educational purpose are mentioned such as; "To encourage positive relationship between users with common interests", "socially contacting students creates an active use", "improving students cognitive and social skills" (West et al., 2009; Kabilan et al., 2010; Chrostofides et al.,2009; Ross et al., 2009; Lampe et al., 2008 adapte (Oktavia et al., 2019) qtd from (Bicen \& Uzunboylu, 2013)).

Regarding the language learning, social media can be called as "activities" as tools mediating learners and the learning objects. Below is concept learning theory based Engeström (1987, taken from (Ibrahim, 2018).

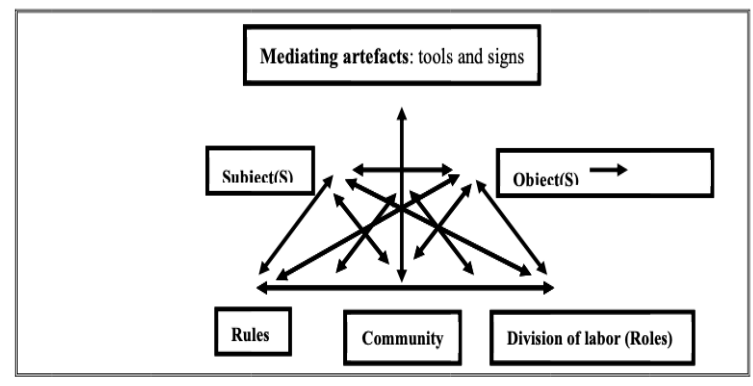

Image 5. Activity system (based on Engeström, 1987, 1999)

As shown in image above, according to activity theory all human activity considered to object(s)-oriented and subjects' actions towards objects in activity system are mediated by four inter-related mediators namely mediating artifacts, rules, community, and division of labor. Here social media, internet usage, computers are included in technical artifacts under mediating artifacts. Furthermore it is important to note that the communication of these four mediators in informal learning activities at residential college should be perceived holistically as a collaborative knowledge construction process as each part in the activity system is in continuous interactions with the others. In general the theory talks about how the use of social media can influence the nature of external behavior and also the mental functioning of individual learner-users.

In the field of hospitality and tourism, social media is one of the most powerful tools to promote and sharing information in various perspectives. Hospitality and Tourism students are encouraged to use social media as a tool in engaging theories and practice in the professional world. As a means to preparing them entering the industry, social media also can provide the students with real data and interactions throughout various kinds of communication. English in this part plays an important role as a medium of interaction, therefore it is important for Hospitality and Tourism are familiar with culture of English communication in social media. During the pandemic, kinds of learning tools including social media is used as an authentic material where students can expose themselves with the language in different types and styles.

The following research is intended to find out how far the influence of social media and its roles throughout the students language learning progress, especially for Hospitality and Tourism students in Universitas Bunda Mulia. Due to full-online learning since last 2020, the students have to face several online materials and also becoming independent learners where most of the materials relying to their own skills in gathering information.

\section{RESEARCH METODOLOGY}

\section{Research Design}

This research applied qualitative design based on the questionnaire asking the students 
perspective toward the use of social media in enhancing their language learning. The questionnaire used Likert-scale from $1-5$ that measures from strongly disagree to strongly agree. The items are also asking the students social media preferences dealing with the language learning.

\section{Participants}

There are 62 students from semester 2 until 8 majoring Hospitality and Tourism in Bunda Mulia University. All of the students have taken some English courses such as Bahasa Inggris 1 dan 2, English for Tourism, and other subjects that use English as medium instructions.

\section{Instruments}

The questionnaires is distributed online from Google form and analyzed statistically to get the average score. There are 27 items asked and basic information filled in as the respondents demographic background. The personal information is remained hidden in order to value the students response and originality.

\section{FINDINGS AND DISCUSSIONS}

Based on the result, there are 62 respondents involved in the questionnaire, and below is how the data distributed between semesters. Most of the respondents were in the semester 2 and 4 where most English subjects are delivered.

Semester

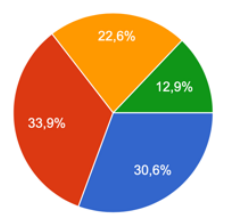

$: 2$
$: 4$
$: 6$
08

Image 6. The students' semester

Furthermore, the data following shows the most social media used by the students.

\section{Image 7. Most-used social media platforms}

It can be seen that Instagram is the most used social media by the students, following by Youtube, Twitter, and Tiktok. Surprisingly, none of the respondents select Facebook. There are many possible reasons, such as the public exposure which and also because the features that is no longer interested for the younger user accounts.

Based on the overall results, the discussion is taken from the five-highest agrees and disagrees responses. Below is the discussion

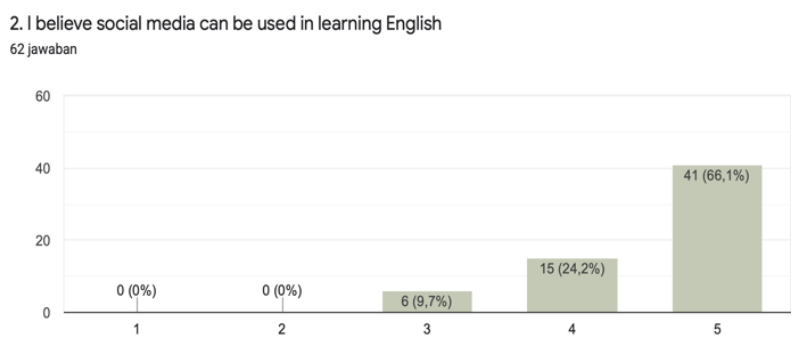

Graph 1. I believe social media can be used in learning English

The result shown that most of the respondents agrees that they can make use the social media. In line with this result the following data shows that social media makes the learning process becomes more fun and interesting.

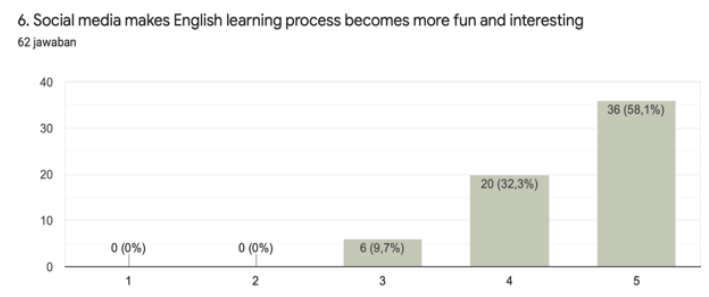

Graph 2. Social media makes English learning process becomes more and interesting. 
More than half of the respondents agree to the ideas on how the involvement of social media can be interesting once it comes to language learning process. As we have all known that some features such as comment sections, likes buttons offer their users either to be more encouraged in share or posting their ideas dealing with the phenomena their posts.

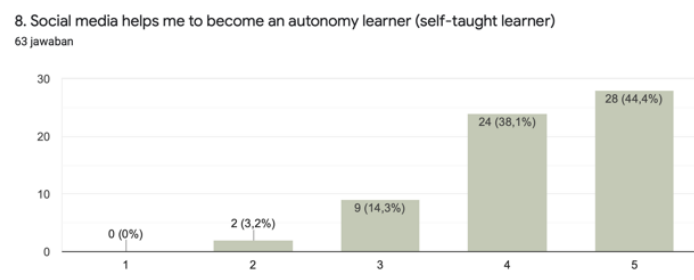

Graph 3. Social media helps me to become an autonomy learner (self-taught learner)

Based on the graph above, another result shows that students can be autonomous learners once they engaged with the social media. Some activities such as group discussions, commenting section and information provided either as articles or infographic are tools that students can use as learning sources.

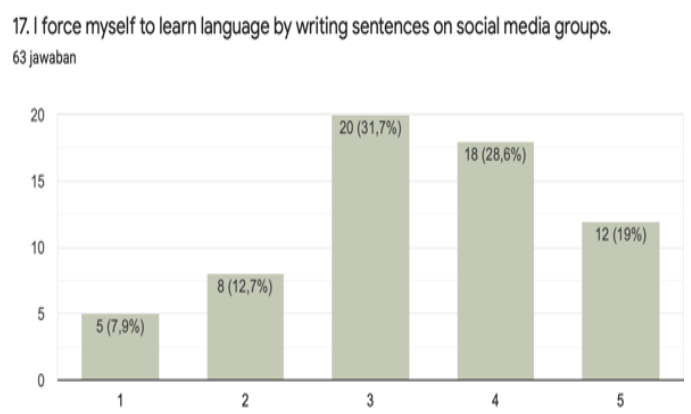

\section{Graph 4. I force myself to learn language by writing sentences on social media groups.}

Based on the result above, most of the students are agree that social media can be one of their language learning tools. This can be seen from the features offered by the social media where most of them are in English. Moreover, captions and comments are often also in English especially once they join group that have members from international. Here, students automatically will likely to comment or put caption in English. They might observe how to express the idea in English correctly and well-understood by other users.

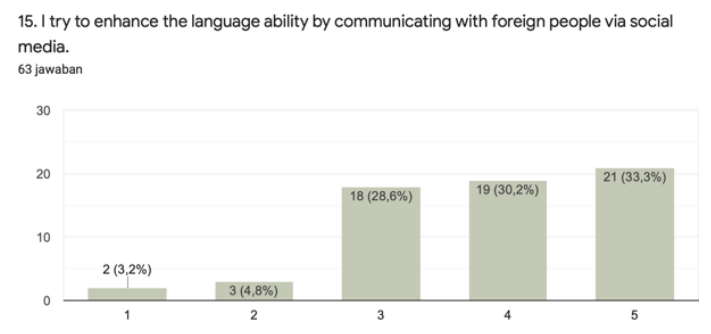

Graph 5. I try to enhance the language ability by communicating with foreign people via social media.

In line with the previous result that states social media can help them in expressing English better, this item emphasizes that students are actually active users in English especially when they are communicating with foreigners. They do not show hesitation or feeling unconfident as if they were in the classroom where sometimes they could feel their English is not really good. In fact, they afraid in making mistakes especially in grammar use. The following result shows most of the students are quite confident in using their English in making posts.

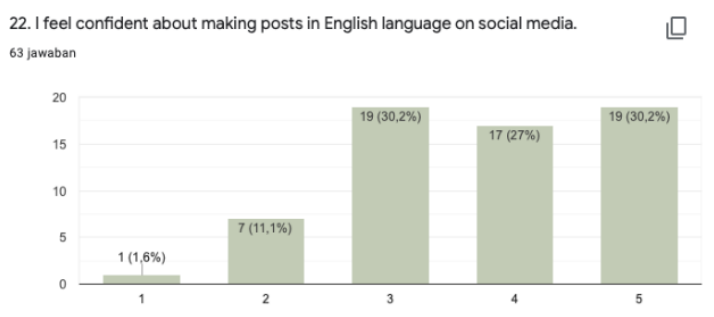

Graph 6. I feel confident about making posts in English language on social media.

The result below also supports the previous perceptions, where students tend to use chat room and use their English to communicate with foreigners users. 


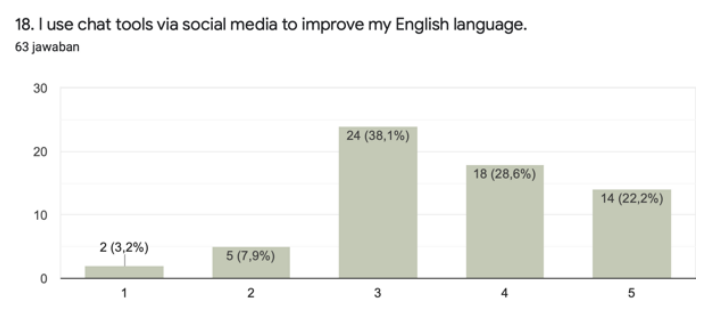

Graph 7. I use chat tools via to improve my English language.

Furthermore, some results also show that various language skills are activated once the students engaged with the social media. Below are some results.



Graph 8. I try to understand news in English while reading them on social networks.

First, it can be seen that the students also becoming active readers. Information in social are sometimes share in English, as a result they have understood some phrases and English texts well in order to get the information right. Therefore whenever they find difficulties in understanding the vocabulary, they tend to use online dictionaries. The result is also showing below.

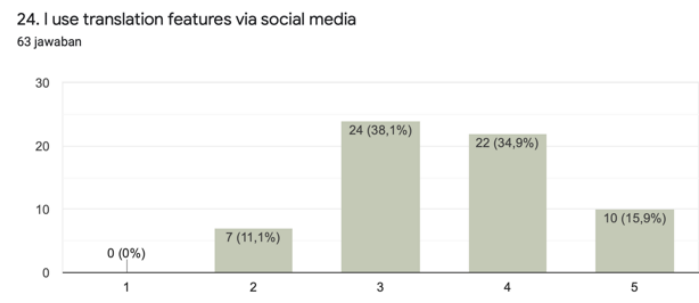

\section{Graph 9. I use translation features via social media.}

Second, besides reading, students are also apparently actively practice their writing skills in social media by participating in comment posts.

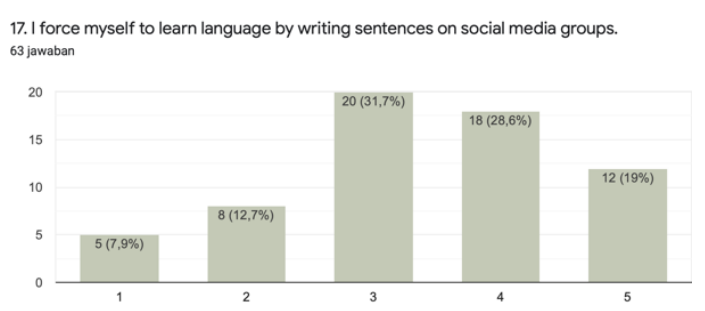

Graph 10. I force myself to learn language by writing sentence on social media groups.

Not only practicing English skills, some features in the social media can also be useful for the students in enchancing their language usage. For example images or visual media where those are often found in some post sharing. Below is the result.

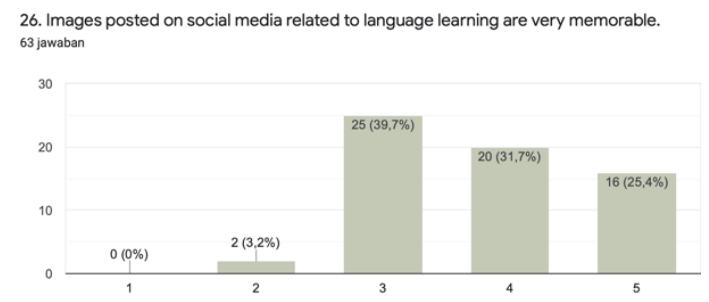

Graph 11. Images posted on social media related to language learning are very memorable.

Also the translation tools and video posts can be used as language learning tools. The following is how the students perceive those features usage.

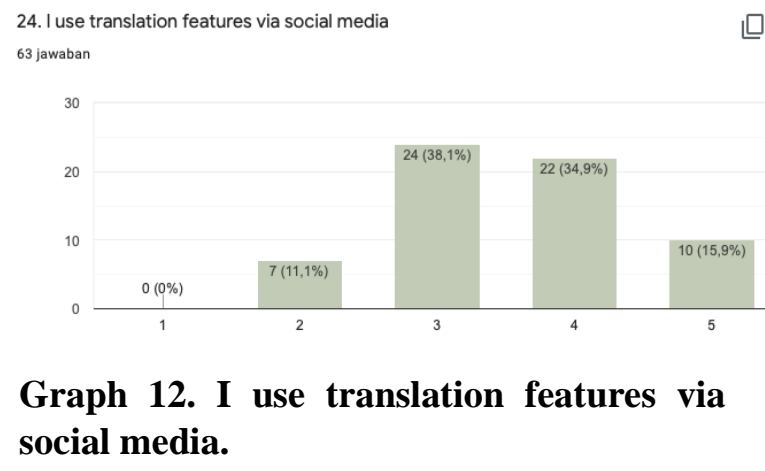

Graph 12. I use translation features via 
21. I pay attention to the sentence patterns and accent while watching videos through social media sites

63 jawaban



Graph 13. I pay attention to the sentence patterns and accent while watching videos through social media sites.

It can be seen that students are basically agree to the use of social media features as part of their process either in producing or receiving the language.

On the other hand this result shows on how social medial can help the students during their language learning process, this item also confirmed that students disagree on the perception how social media give negative impacts to their English language. Even though most of the time, students are sometimes hesitate to express their English whenever they are in the classroom, this perception actually shows different result. It seems that they become confident in expressing their English in the social media.

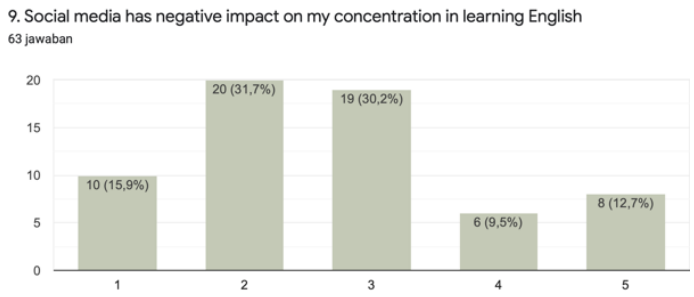

\section{Graph 11. Social media has negative impact on my concentration in learning English.}

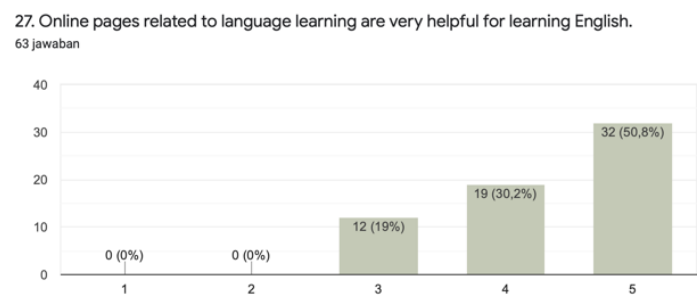

Finally, the last result is showing besides students make use some features in social media and how they involve in groups as well, learning is becoming more fun and enjoyable. Below is the result.

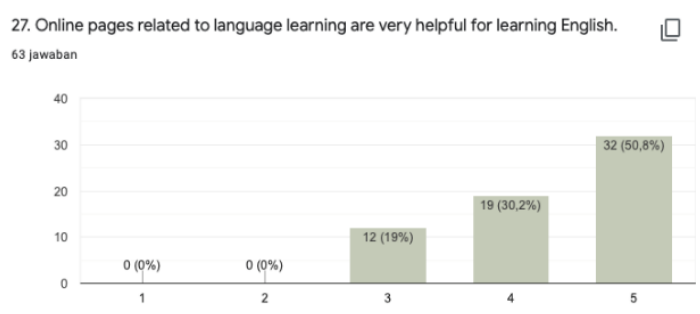

Graph 14. Online pages related to language learning are very helpful for learning English.

\section{CONCLUSIONS}

Based on the findings above, it can be seen that there are many learning aspects that the students can gain through social media. First one is from the motivational aspect, here students feel that engaging with others from different country could make them feel more confident in using their language comparing in the classroom. The purpose of using English is basically for communication, therefore the goal is actually achieved automatically once they access social media as part of their daily activities. They also do not need to worry to produce errors or mistakes since there will not be any teachers to correct their language production. They also do not need to feel ashamed once they make mistake, in fact they learn from using the language carefully by consulting translation tools or other features.

Second part, is how social media can activate the language skills such as speaking, when they access the chatting forum. Reading skill, when they read certain information from various kinds of articles. Writing skill, also actively used especially when they put comments and put captions for every post they shared. Sentence structures or grammar skill is also trained, whenever they want to make sure that their language production is acceptable and correctly used. 
Lastly, the students can creatively use certain features and application in the social media either as their learning tools or as part of their expression in posting any information in the accounts feed.

\section{REFERENCES}

Bicen, H., \& Uzunboylu, H. (2013). The Use of social networking sites in education: A case study of Facebook. Journal of Universal Computer Science, 19(5), 658-671. https://doi.org/10.3217/jucs019-05-0658

Christofides, E., Muise, A., \& Desmarais, S. (2009). Information disclosure and control on Facebook: Are they two sides of the same coin or two different processes. CyberPsychology \& Behavior, 12(3), 341-345.

Engeström, Y. (2001). Expansive Learning at Work: Toward an activity theoretical reconceptualization. Journal of Education and Work, 14(1), 133-156. https://doi.org/10.1080/1363908002002 8747

Ibrahim, C. W. I. R. B. C. W. (2018). Social Media Tools for Informal Language Learning: A Comprehensive Theoretical Framework. Asian Social Science, 14(4), 46. https://doi.org/10.5539/ass.v14n4p46

Kabilan, M.K., Ahmad, N. \& Abidin, M.J.Z. (2010). Facebook: An online environment for learning of English in institutions of higher education? Internet and Higher Education, 13, 179-187.

Lampe, C., Ellison, N., \& Steinfield, C. (2008). Changes in use and perception of Facebook. In B. Begole \& D. W. McDonald (Eds.), CSCW '08 Proceedings of the 2008 ACM conference on Computer supported cooperative work (pp. 721-730). New York, NY, USA: ACM.

Oktavia, Y., Husda, N. E., \& Suhardianto, S. (2019). Kecakapan Berkomunikasi
Berbasis English For Tourism Bermuatan Kearifan Lokal Masyarakat Kavling Seroja Kota Batam. Jurnal Pengabdian Kepada Masyarakat, 25(4), 185.

https://doi.org/10.24114/jpkm.v25i4.148 30

Ross, C., Orr, E. S., Sisic, M., Arseneault, J. M., Simmering, M. G., \& Orr, R. R. (2009). Personality and motivations associated with Facebook use. Computers in Human Behavior, 25(2), 578-586.

West, A., Lewis, J., \& Currie, P. (2009). Students' Facebook 'Friends': Public and private spheres. Journal of Youth Studies, 12(6), 615-627. 